\title{
A utilização do portfólio reflexivo como método de ensino, aprendizagem e avaliação na disciplina Políticas de Saúde
}

Thiago Queiroz Meneses, Michelly de Souza Faria, Luciana Saraiva da Silva, Rosângela Minardi Mitre Cotta, Glauce Dias da Costa

\begin{abstract}
Resumo
O Portfólio Reflexivo (PR) é um método de ensino, aprendizagem e avaliação, que visa a formação de profissionais críticos, reflexivos, criativos, autônomos e participativos, conforme orienta as Diretrizes Curriculares Nacionais. Apresentar a experiência de utilização do portfólio reflexivo, como método inovador de ensino, aprendizagem e avaliação, na disciplina Políticas de Saúde, no primeiro semestre de 2016 na Universidade Federal de Viçosa (UFV). Trata-se de um relato de experiência dos estudantes dos cursos de Enfermagem e Nutrição que cursaram a disciplina Políticas de Saúde no primeiro semestre de 2016, sobre a utilização do PR como método de ensino, aprendizagem e avaliação. O uso do PR na disciplina Políticas de Saúde foi de extrema relevância no processo de aprendizagem dos alunos, desenvolvendo o pensamento crítico, reflexivo, além da criatividade e ética. $\mathrm{O}$ início da construção do PR foi difícil, tendo em vista que os estudantes ainda não estavam familiarizados com a metodologia, e muitas vezes já traziam pré-conceitos que desestimulavam o trabalho. No entanto, ao longo de sua construção, foi possível verificar o potencial inovador e dinâmico do método, que fortalece a autonomia, a criatividade, o trabalho interdisciplinar e em equipe, potencializa a reflexão das práticas, assegurando a construção do conhecimento e o desenvolvimento pessoal e profissional dos envolvidos (docentes e discentes). $\mathrm{O}$ PR também foi utilizado como método de avaliação formativa, que ocorreu em quatro etapas e foi extremamente útil para que os alunos tivessem um direcionamento e pudessem ver as fortalezas e fragilidades do trabalho, tendo a oportunidade de corrigir os seus erros. Todo o processo avaliativo ocorreu por meio de critérios claros, que avaliavam o envolvimento e participação de cada indivíduo e do grupo como todo. Por fim, destaca-se que a reação de frustação e negatividade do primeiro momento se transformaram em uma reação de aceitação e superação dos conceitos desfavoráveis previamente estabelecidos, e ao final de sua construção emergiu a satisfação dos envolvidos por ser um método útil e aplicável. O uso do portfólio permitiu ainda, relacionar o conhecimento prévio dos estudantes com o conhecimento adquirido na disciplina e integrar a vida pessoal, acadêmica e profissional. O PR é um método eficaz de ensino, aprendizagem e avaliação, que permite o desenvolvimento de importantes habilidades, como o aprender a trabalhar em equipes, a lidar com situações adversas, desenvolvendo pensamento crítico acerca de assuntos atuais e importantes na formação de um profissional da área da saúde.
\end{abstract}

Descritores: Portfólio reflexivo; Políticas de Saúde; Discentes; Método Ativo. 